\title{
ポーラスコンクリートブロックと吸リン材を含む池の水質とリン·窒素収支
}

\author{
相子伸之 ${ }^{1} \cdot$ 瀬戸昌之 $^{2}$
}

\section{Water Quality, and Phosphorus and Nitrogen Balance in a Pond with Porous Concrete Block and Phosphorous Absorbent}

\begin{abstract}
Nobuyuki Aiko ${ }^{1}$ and Masayuki Seto ${ }^{2}$
Abstract: Effects of porous concrete block and phosphorus absorbent on water quality purification of a pond are investigated. The pond of the interest is of $40 \mathrm{~m}^{3}$ in water storage capacity and $160 \mathrm{~cm}$ in depth. Volumetric rates of the water purification materials of the blocks and the absorbents to the pond capacity are $2.5 \%$ and $1.2 \%$, respectively. To make it possible for the whole body of water to contact the materials, the pond water is circulated with a pump of $80 \mathrm{~L} / \mathrm{min}$. As a result, the degree of transparency of the water in the pond has remained more than $160 \mathrm{~cm}$ for more than six years. Concentrations of total phosphorus (TP) and total nitrogen (TN) have been in the range of a detection minimum $(<0.003 \mathrm{mg} / \mathrm{L})$ to $0.026 \mathrm{mg} / \mathrm{L}$ and a detection minimum $(<0.2 \mathrm{mg} / \mathrm{L})$ to $4.7 \mathrm{mg} / \mathrm{L}$, respectively. Loads of TP and TN to the pond from the external sources such as tap water, rain and fallen leaves are $48 \mathrm{~g} /$ year and $5,300 \mathrm{~g} /$ year, respectively, while their removals from the pond, including by sediment removals from the phosphorus absorbent tank, are $24 \mathrm{~g} /$ year and $1,800 \mathrm{~g} /$ year, respectively. The difference in TP between the amount of loads and removals is roughly identified with $20 \mathrm{~g} /$ year of the accumulation amount that could be calculated from the distribution of TP in the pond. However, the difference in TN, $3500 \mathrm{~g} / \mathrm{year}$, deviates from $300 \mathrm{~g} / \mathrm{year}$ estimated from its distribution. This disparity is considered to balance with the nitrogen loss resulting from denitrification.
\end{abstract}

Keywords: Transparency; Total phosphorus; Total nitrogen; Phosphorus and nitrogen balance

1 はじめに

親水を目的とした池が公園などに造られている.しかし ながら大半の池水は, アオコなどの植物プランクトンの 大量増殖で污濁している. 植物プランクトンは, 水中の リンや窒素などの栄養塩類濃度が高ければ,これらを 利用して増殖し, 水は污濁する(相崎, 1992 ; 渡辺, 1994:木村·瀬戸, 1998a; 大村·瀬戸, 2001). 植物プラ ンクトンの増殖を抑制し，池水を清澄に維持するため に, 水中のリン・窒素濃度を低下させる必要がある. し かしながら, 透視度 $50 \mathrm{~cm}$ 以上の高い透視度を維持す るための目標値は, 全少 (以下, TP) 濃度で $0.01 \mathrm{mg} / \mathrm{L}$ 以下, 全室素 (以下, $\mathrm{TN}$ ) 濃度で $0.2 \mathrm{mg} / \mathrm{L}$ 以下のきわめ て低濃度にする必要がある(木村・瀬戸, 1998a). 多く の浄化法ではTP・TNをこの目標值に下げるのに充分 な能力がないため, 高い透視度を維持できない.ま た, 能力が充分であっても, 装置が複雑であったり, メ ンテナンスが煩雑であったりすることもしばしばある.

著者および共同研究者は, ポーラスコンクリートブロ ック（以下，ブロック）と吸リン材を用いた池水浄化法 で, 水中のTP·TN濃度を低下させ, 透視度を高くする ことに成功している(木村・瀬戸, 1998b; 末次·瀬戸, 1998; 相子·瀬戸，2001）. しかしながら, 野外の池にお いて長期間高い透視度を維持した例は少ない. また, 净化材を投入した池における物質収支も不明な点が 多い.

そこで本研究では, 浄化材を投入した池で長期的 な水質調查を行い，簡単なメンテナンスで高い透

\footnotetext{
${ }^{1}$ 東京農工大学連合農学研究科博士課程 Ph.D. Student, United Graduate School of Agricultural Science, Tokyo University of Agriculture and Technology, 3-5-8 Saiwai-Cho, Fuchu, Tokyo, 183-8509 Japan

${ }^{2}$ 東京農工大学共生科学技術研究部 Institute of Symbiotic Science and Technology, Tokyo University of Agriculture and Technology, 3-5-8 Saiwai-Cho, Fuchu, Tokyo, 183-8509 Japan
}

視度を長期間維持できるか検討した. また,この池に おけるリン・窒素分布とそれらの収支を把握することに より, 本浄化法の浄化機構を明らかにし, より有効かつ 適切な池水管理のあり方を検討した.

\section{2 材料と方法}

\section{1 池の概要}

実験を行った池は, 貯水容量約 $40 \mathrm{~m}^{3}$, 面積 $42 \mathrm{~m}^{2}$, 周 辺の水深 $70 \mathrm{~cm}$, 中心の水深 $160 \mathrm{~cm}$ のコンクリート張りの 池である. 池には水道水を $1.5 \mathrm{~L} / \mathrm{min}$ の流量で連続的に 流入させた.この池には体長約 $10 〜 30 \mathrm{~cm}$ のコイを70匹 程度入れた.コイのえさは人為的には与えなかった。 池の周辺は木々に囲まれており,それらの木々から池 に落葉があった.

\section{2 浄化材}

ブロックは広い表面積を有し, カルシウムを多く含む材 料からなる(木村・瀬戸, 1998b). カルシウムとリンとの 不溶性塩の形成やブロックの表面に付着した微生物 によるリンの吸収により, 池水からのリン除去が期待で きる. 吸リン材 ((株)クレアテラ) は鉄・アルミニウムを多 く含み, 反応性リンの吸着能力が高い火山灰土蟺を基 材とし, 吸リン能力を高めるために硫化鉄を加えて $500^{\circ} \mathrm{C}$ で焼結した粒状 (直径 $2 \sim 5 \mathrm{~mm}$ ) の物質である (木村·瀬戸, 1998b). 糠信ら (1998)は, 吸少材のTP の化学的吸着量を1 Lあたり $60 \mathrm{mg}$ と報告している. 净化 材表面や内部では付着微生物によってリン・窒素が取 り込まれ, さらに嫌気的な部位での脱窒作用も期待で きる.

この池は浄化前に底泥を除去し, 1997年から現在の 池水浄化を開始した.このときの净化材投入密度は, 水との体積率で, ブロックが $2.5 \%$, 吸リン材が $1.0 \%$ であ った. その後, 1999年に $0.02 \mathrm{~m}^{3}, 2000$ 年と 2001 年に $0.04 \mathrm{~m}^{3}$ ずつの吸リン材を加え, その密度は $1.2 \%$ とした. 
ブロックは池の中に直接投入した. 吸リン材は, 水槽 $($ 縦 $70 \mathrm{~cm} \times$ 横 $100 \mathrm{~cm} \times$ 高さ $60 \mathrm{~cm})$ に入れ，池の外に設 置した。吸リン材は10L程度に小分けして網袋に入れ

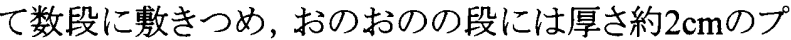
ラスチック製の網を敷いて吸リン材同士が重ならないよ うにした. 池水は, ブロックを通過し，吸リン材の水槽の 下方から流入 $(80 \mathrm{~L} / \mathrm{min}) し$, 上方から池に戻るように循 環させた。

\section{3 浄化材洗浄}

投入後, ブロックは全く洗浄しなかった. 吸リン材は, 年 に0〜数回, 水道水で軽く洗い流した.この操作は, 吸 リン材の粒子の間に蓄積した堆積物を取り除くことによ り,これに含まれるリンと窒素を池外に除去するためで ある.なお, 2002年以降はこの操作の軽減のために, 吸リン材の水槽にいくつかの穴をあけた塩化ビニル製 の管を設置し，この管にブロワで空気を $80 \mathrm{~L} / \mathrm{min}$ の速さ で吹き込んで, 空気の上昇で水槽内を擋乱し，堆積物 を除去した. 除去した堆積物を含む水は池の外に排除 した.

\section{4 水質測定}

透視度は採水時に透視度計 (SANPLATEC，0〜 $50 \mathrm{~cm}$ )を用いて測定した。また，50cm以上の透視度 は、水面から投げ入れた1円玉が確認できる深さを測 定し，これを透視度とした. 採水した水は速やかに持ち 㷌り, 実験室で以下の測定を行った. TP濃度は, ペル オキソ二硫酸カリウムで酸化分解し，モリブデン青法に より呈色反応させ, $n$-ブタノールで抽出・濃縮して測定 した（日本水道協会, 1997). 反応性少ン (RP) 濃度は, 孔径 $0.45 \mu \mathrm{m}$ のメンブレンフィルターでろ過した後に, モリブデン青法により測定した. TN濃度は, アルカリペ ルオキソ二硫酸カリウム分解一紫外線吸光法 (日本水 道協会, 1997) で測定した.アンモニア態, 覀硝酸態, 硝酸態窒素濃度はイオンクロマトグラフ (Shodex CD-4 (昭和電工) ; SCK01 (三菱化学)，またはIC I-524A(昭 和電工) カラム装着)で測定した.

\subsection{TP - TNおよび脱窒菌数の分布の測定}

\subsection{1 生試料の採取}

ブロックの付着微生物は, 池に設置したブロックの表面 をブラシで擦り取って得た. 壁面の付着微生物は, ナ イフで切り取って得た. 吸リン材の粒子の間に蓄積した 堆積物は，池から持ち帰った吸リン材をイオン交換水 に入れ攪找し，吸少材の粒子を取り除き懸濁液を得 た. 池底に蓄積した堆積物（以下，底泥）は水深 $1.6 \mathrm{~m}$ の池底から手動ポンプで得た。

\subsection{2 付着微生物と堆積物の測定}

TP・TNを測定するために，採取した生試料の一部は $100^{\circ} \mathrm{C}$ で乾燥した後, 乳鉢と乳棒ですり潰し, 乾燥試料 を得た. TP濃度はモリブデン青法で, TN濃度はC/Nコ ーダー(Yanaco, MT-700)で測定した。

脱窒菌数を計数するために，採取した生試料をイオ ン交換水に入れ，ホモジナイザー(日本精機, AM-7) で試料懸濁液を得た.この懸濁液の脱窒菌数をGiltay 培地を用いたMPN法で計数した。

\subsection{3 計算}

水中, ブロック, 壁面上の付着微生物, 吸リン材槽に蓄 積した堆積物中, 底泥中の単位面積または単位体積 当たりのTP・TN濃度, および脱窒菌密度から池のそれ ぞれの場所における池あたりのTP・TN量, および脱窒 菌群数を算出した. また, 魚のTP・TN量は湿重量: 乾 重量:TP:TNがおよそ330:100:2:10として算出した.

\section{3 結果}

\section{1 水質の経時変化}

この池は6年間, $50 \mathrm{~cm}$ 以上の高い透視度を維持し(図 1)，ほとんどの測定值は $160 \mathrm{~cm}$ 以上であり池の底まで 確認できるほど透明であった。 TP濃度は検出下限 $(0.003 \mathrm{mg} / \mathrm{L})$ 以下 0.026mg/Lで推移し, ほとんどの測 定値は $0.01 \mathrm{mg} / \mathrm{L}$ 以下であった. RP濃度は常に検出下 限 $(0.003 \mathrm{mg} / \mathrm{L})$ 以下であった。TN濃度は検出下限

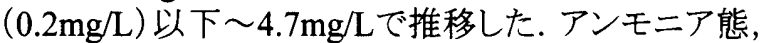
亜硝酸態窒素は常に検出下限 $(0.1 \mathrm{mg} / \mathrm{L})$ 以下であつ た. 硝酸態窒素濃度は検出下限 $(0.1 \mathrm{mg} / \mathrm{L}))$ 以下〜 $4.7 \mathrm{mg} / \mathrm{L} て ゙$ 推移し, 水中のTNのほとんどは硝酸であっ た.

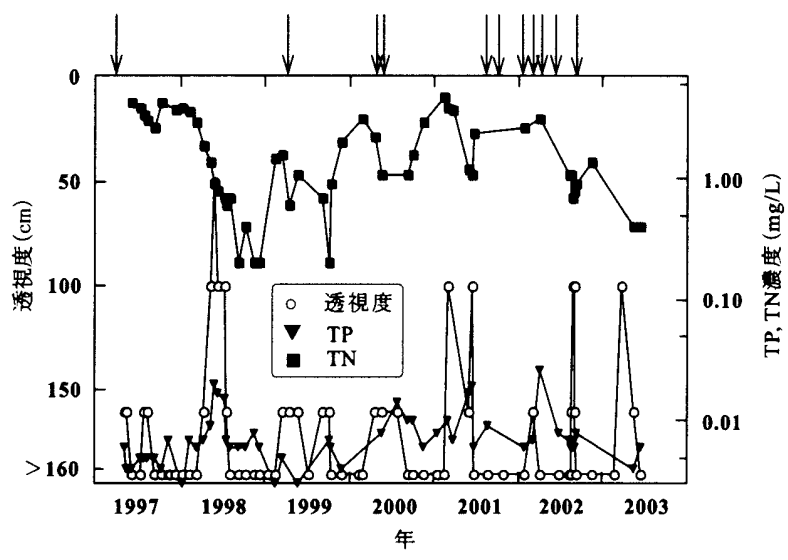

図 1: 池水中の透視度, TP, TNの経時変化 （浄化材としてブロック，吸少ン材をそれぞれ $2.5 \%(\mathrm{v} / \mathrm{v}), 1.2 \%(\mathrm{v} / \mathrm{v})$ 投入した. 矢印は吸少 材槽の堆積物の除去を示寸.)

\section{2 池のリン・窒素分布}

池ではTP・TNの多くが底泥に存在していた(図2)。そ の量はそれぞれ $115 \mathrm{~g}, 1,500 \mathrm{~g} ゙$ け，水中に存在する

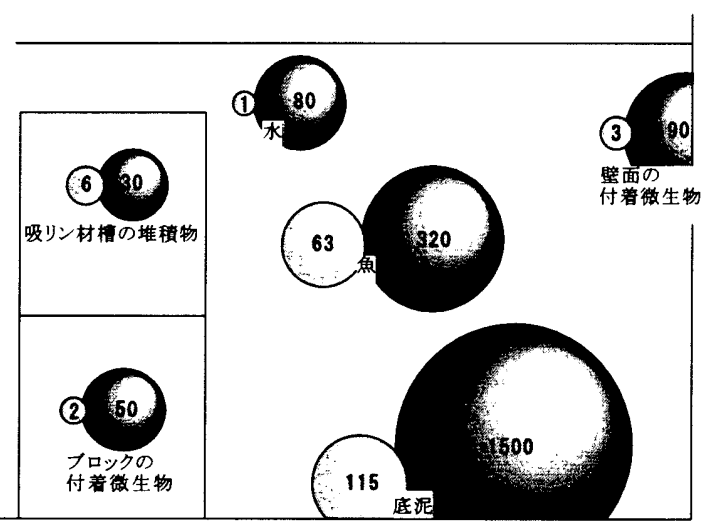

図 2: 池の水, 魚, 生物膜および堆積物のTP $($ ), TN (○)の分布 (単位:g)

(試料は2002年8月に採取したもの $(n=3))$ 


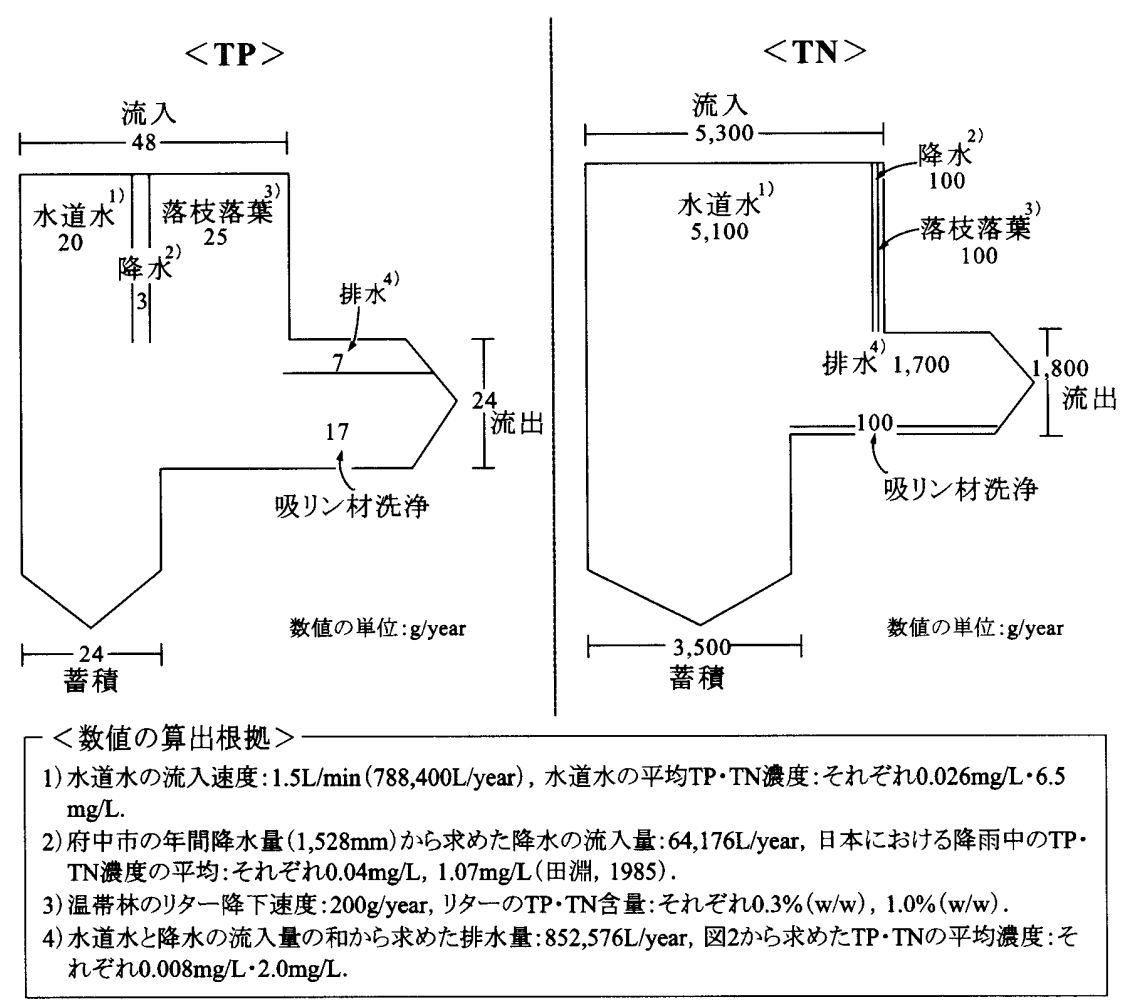

図 3: 池の TP・TN 収支

量のそれぞれ115倍・19倍に相当した．底泥は，1997 年から少しずつ蓄積がみられ, 2002年の夏には平均の 深さは4.0cm $(n=40, \mathrm{SD}=4.0)$ であった（図には示してい ない).

\section{3 池におけるリン・窒素収支}

池には水道水, 降水, および落枝落葉から $48 \mathrm{~g} /$ yearの TPが流入した(図3).この流入のうち, オーバーフロー の排水と吸少ン材洗浄で $24 \mathrm{~g} / \mathrm{year}$ のリンが流出した. 流 入と流出の差から得られる池への蓄積量は $24 \mathrm{~g} /$ yearと 算出された。

実験池には水道水, 降水, および落枝落葉から年間 $5,300 \mathrm{~g} / \mathrm{year}$ の窒素が流入した(図3).この流入のうち, オーバーフローの排水と吸リン材洗浄で $1,800 \mathrm{~g} / \mathrm{year}$ の 窒素が流出した. 流入と流出の差から得られた池への 蓄積量は3,500 g/yearと算出された。

\section{4 池の脱窒菌数}

脱窒菌数は水, 吸リン材槽, および底泥の中に多く存 在していた(表1).

表 1: 池の水, 生物膜, 堆積物中の脱窒菌数の分布

\begin{tabular}{lrl}
\hline \multicolumn{1}{c}{ 試 料 } & 脱窒菌数 $\left(\times 10^{7} \mathrm{MPN}\right)$ \\
\hline 水 & 9.2 & -92.0 \\
ブロックの付着微生物 & $0.0-0.2$ \\
壁面の付着微生物 & $1.4-5.8$ \\
吸リン材槽の堆積物 & $19.0-21.0$ \\
底泥 & $30.0-67.0$ \\
\hline
\end{tabular}

\section{4 考察}

ブロックと吸リン材をそれぞれ $2.5 \%, 1.2 \%$ 投入した池で は, $50 \mathrm{~cm}$ 以上の高い透視度を 6 年以上維持し，ほとん どの場合, $160 \mathrm{~cm}$ 以上のより高い透視度を示した（図 1).これだけの長期間にわたって，高い透視度を維持 した浄化法は, 著者らの知るかぎりではほとんどない， その間, ブロックは入れたまま洗浄せず, 吸少ン材洗浄 は年0〜 5回の低頻度であり, 維持管理も簡単であつ た. 相子・瀬戸(2001) は, ブロックと吸リン材が, それぞ れ $10 \%$ と $2 \%$ のときでは 5 年間, $20 \%$ と $4 \%$ のときでは 6 年 間以上, 特別な維持管理をせずに $50 \mathrm{~cm}$ 以上の透視度 が維持できたことを報告した. 本報告で浄化材の投入密 度が低くても吸リン材洗浄をして, 高い透視度が維持 できることを実証した。また，2002年から行ったブロ ワによる吸リン材洗浄でも効果が得られ，この装置を 設置しておけば，1人でも簡単に洗浄ができるように なった.

水中の TP・TN濃度は常に水道水よりも低くなり, 特 にTP濃度はほとんどの測定時において $0.01 \mathrm{mg} / \mathrm{L}$ 以下 であった(図1). 木村・瀬戸(1998)は, 池水管理のた めの TP・TN濃度目標值をそれぞれ $0.01 \mathrm{mg} / \mathrm{L} \cdot 0.2$ $\mathrm{mg} / \mathrm{L}$ とて, どちらか一方をこの濃度以下にするか, も しくはTP・TN濃度の両方を下げてこの值に近づけるこ とで $50 \mathrm{~cm}$ 以上の透視度が維持できると報告している. この池では多くの場合, TP濃度が低く, TP濃度が高ま ったときでも TN濃度が低かったために $50 \mathrm{~cm}$ 以上の高 い透視度が維持できたと考えられる.

TP·TNは水中にはほとんど存在しておらず, 底泥に 多く存在していた (図2)。この量は水のTP・TNの115 倍・19倍であり，これらが巻き上がりや溶出で水に放出 寸れば, 水のTP・TN濃度は跳ね上がり, 水は罍るであ 
ろう.しかしながら，水のTP・TNの濃度は低く維持され たのだから，底泥から水へのみかけ上の $\mathrm{TP} \cdot \mathrm{TN}$ 放出 はなかったと考えられる. 著者ら(2003)は, 浄化材を投 入した水槽の底泥では, 投入しない水槽よりTP・TN放 出速度が低くなることを報告しており，浄化材の投入が この池の底泥のTP・TN放出を抑制していると考えられ る. また, 底泥は, 1997年から2002年までの6年間で蓄 積し, その深さは平均 $4.0 \mathrm{~cm}$ であった. 底泥の体積を, 池の底面積 $42 \mathrm{~m}^{2}$ から算出すると $1.7 \mathrm{~m}^{3}$ であった. この量 は, 水量に比べて小さく, そのため底泥の蓄積による 池の埋没については, 数十年間は考慮する必要はな いと考えられる.

池に流入した $48 \mathrm{~g} /$ yearのTPのうち, $24 \mathrm{~g} /$ yearが流出し た.この $24 \mathrm{~g} /$ yearのうち, $17 \mathrm{~g} /$ yearの大部分が吸リン材 洗浄で除去されており, 積極的に吸少材を洗浄する ことにより池に蓄積するTPを除去することが可能である と考えられる。一方, TNは 5,300g/yearが流入し, $1,800 \mathrm{~g} /$ yearが流出した. この $1,800 \mathrm{~g} /$ yearのうち, 吸少 材洗浄で除去されるのは $100 \mathrm{~g} / \mathrm{year}$ の少量であり, 㗌素 の除去に吸リン材洗浄は有効ではなかった.

TPの流入 $48 \mathrm{~g} /$ yearと流出 $24 \mathrm{~g} /$ yearの差から得られた 池への蓄積量は $24 \mathrm{~g} /$ yearであり,このTPは, 壁面, ブロ ックの付着微生物一の吸収, 底泥への堆積, および吸 リン材へ化学吸着したことが考えられる.ここで, 池の TP分布 (図2)から蓄積したリンの収支について考察す る(表2). それぞれの場所には，净化材設置時の1997 年から分布量を測定した2002年までの約6年間にTPが 蓄積したと仮定すると, 図2で示した分布量を6年で割 ると年あたりの平均蓄積量が得られる. ブロック, 壁面 の付着微生物にそれぞれ $0.3 \mathrm{~g} / \mathrm{year}, 0.5 \mathrm{~g} / \mathrm{year}$, 底泥に は19.2g/yearのTPが蓄積しており,これらの合計は $20 \mathrm{~g} / \mathrm{year}$ とる. 流入と流出の差から得られた池への蓄 積量 $24 \mathrm{~g} / \mathrm{year}$ CP 分布から得られた蓄積量は概ね一 致し, これらの蓄積量の差は $4 \mathrm{~g} / \mathrm{year}$ のさい值になっ た. また,この4g/yearは吸少材に化学的に吸着したこ とも推定される.

表 2: 池における TP・TN の蓄積速度

\begin{tabular}{|c|c|c|}
\hline 蓄 積 速度 (g/year) & TP & $\mathrm{TN}$ \\
\hline 流入と流出の差 ${ }^{1)}: \mathrm{A}$ & 24.0 & 3,500 \\
\hline 測定値の合計 ${ }^{2)}$ : B & 20.0 & 287 \\
\hline ブロック上の生物膜 & 0.3 & 5 \\
\hline 壁面上の生物膜 & 0.5 & 32 \\
\hline 底泥 & 19.2 & 250 \\
\hline$A-B$ & 4.0 & 3,213 \\
\hline
\end{tabular}

一方, TNの流入 $5,300 \mathrm{~g} / \mathrm{year}$ と流出 $1,800 \mathrm{~g} / \mathrm{year}$ の差 は3,500g/yearと算出される(図3). ブロック,壁面の付 着微生物, および底泥にそれぞれ $5 \mathrm{~g} / \mathrm{year}, 32 \mathrm{~g} / \mathrm{year}$, および250g/yearが蓄積しており，これらの合計は $287 \mathrm{~g}$ yearであった (表2). 流入と流出の差から得られ た池一の蓄積量とTN分布から得られた蓄積量の差は 3,213g/yearの大きい值を示した. TP収支がこの池の収 支を反映しているのであれば, 測定值に同じ係数を乗 じているTN収支も同様にこの池の収支を反映している であろう. したがって,この3,213g/yearのTNは脱窒され たと考えられる.このことから,この池に流入したTNの
34\%はオーバーフローの排水や吸リン材洗浄により流 出し，61\%は脱窒されており，池にはほとんど蓄積し ていないことが考えられた。

池における脱窒菌数(表1) は, 水中, 吸少材槽の 堆積物, および底泥に多く分布していた. 水中のDOは 年間を通じて $8 \sim 9 \mathrm{mg} / \mathrm{L}$ (データには示していない)で あり，水中で脱窒がおこることは考えがたいことから，吸 リン材槽と底泥の嫌気的な堆積物で多くの窒素が脱窒 されていると考えられる. また, ブロックと吸少材の投 入によって底泥の脱窒菌数が増加すること(相子ら， 2003）が明らかになっている.これらのことは，本浄化 法では底泥の除去は必要なく，むしろ脱窒には底泥 を除去しない方が窒素除去に有効であると考えられ る.

本研究で示したTP・TNの流入量 (図3) は, 大きな誤 差を含んでいるかもしれない，たとえば，水道水からの $\mathrm{TP} \cdot \mathrm{TN}$ の流入は濃度に流速を乗じた值で, TP・TN濃 度はほとんど変動しなかったものの流速には土20\%程 度の誤差があった. 落枝落葉からのTP・TNの流入量 は平均的な温帯落葉樹林における降下量 $800 \mathrm{~g}$ (乾燥 重量)にこの池への正味の流入割合 0.25 を乗じて推定 した. 落枝落葉からの流入にはこれらの誤差が相乗さ れ土50\%程度の誤差があろう.これらの誤差は本研究 の池のTP・TN収支にどのように影響するだろうか.

たとえば吸リン材の化学的吸着量に着目する. 糠信 ら（1998）が報告した吸少材の化学的吸着量から, こ の池に投入された吸リン材 $0.5 \mathrm{~m}^{3}$ は $30 \mathrm{~g}$ の $\mathrm{TP}$ 吸着す ると見積もられる. この值を6年で除すると $5 \mathrm{~g} / \mathrm{year}$ 着できる計算になる. ゆえに, 流入と流出の差から得ら れた池への蓄積量とTP分布から得られた蓄積量の差 は0〜5g/yearとなり,これよりTPの流入量は44〜49 g/yearと算出される. したがって, 図3で示したTP流入 量と実際に池に流入した量とは大きくかけ離れていな い.このことから, 同様の方法で算出したTN流出量も 妥当な值であると考えられる.

\section{5 むすび}

本浄化法は, 高密度だけでなく低密度の浄化材投入 でも TP・TN濃度を低下させ, 6 年間以上の長期間にわ たって, 透視度 $50 \mathrm{~cm}$ 以上を維持した. 底泥には水を濁 らせるのに充分なTP・TNが存在していたが, 底泥は除 去する必要がなく, むしろ浄化に貢献していた. また, 本浄化法は塩素や重金属など生物に有毒な薬品など を使わないため, 水, 底泥, 浄化材にはそれぞれをす みかとする生物が生息可能であり, 水は災害時の用水 として使うことも可能であろう. 本法は,「生きている水 辺」を簡単に創出し，かつ維持が簡単な優れた池水浄 化法といえよう。

\section{謝辞}

本研究費の多くの部分は株式会社豊栄, 太平洋セメント 株式会社に負うた. 記して謝意を表する. 本稿の執筆に あたり, 東京農工大学環境微生物学研究室の多羅尾光 徳博士や学兄たちに多くのご提案をいただいた. 記して 謝意を表する.

\section{引用文献}

[1] 相子伸之・瀬戸昌之 (2001): ごく低頻度のメンテナンス で, 長期間にわたつて高い透視度を維持することが可能 な池水浄化法, 多自然研究, 75, pp.3-6. 
[2] 相子伸之・岩本知里・瀬戸昌之（2003）：ポーラスコ ンクリートブロックと吸リン材が底泥を含む水槽の 水質に及ぼす影響，人間と環境，29, pp.107-116.

[3] 相崎守弘 (1992)：水質污濁のメカニズムと浄化技術, 水と緑の読本-特集/公園の水と水辺の管理 , 28, pp. 926-930.

[4] Alexander, M. (1965): Denitrifying bacteria, in Methods of Soil Analysis, Part2, Ed. C. A. Black, American Society of Agronomy Inc., Wisconsin, pp.1484-1486.

[5] 木村綾·瀬戸昌之 (1998a): 都市の人工池におけるリン 窒素の分布と透視度との関係, 雨水技術資料, $\mathbf{3 0}$, pp.69-74.

[6] 木村綾・瀬戸昌之 (1998b) : ポーラスコンクリートブロック と吸リン剂を組み合わせた池水浄化法の提案, 人間と環 境, 24, pp.22-27.

[7] 中川智絵・棣信輝領謹・瀬戸昌之 (2000): 吸少材とポ ーラスコンクリートブロックを組み合わせた池水浄化法を 用いた水槽における添加したリンと窒素の分布, 人間と 環境, 26, pp.110-117.
[8] 日本水道協会 (1997): 上水試験法1993年版, 第四版, pp.180-183.

[9] 日本水道協会 (1997): 上水試験法1993年版, 第四版, pp. 202-203.

[10] 糠信輝領謹・末次康隆・木村綾・瀬戸昌之 (1998): ポー ラスコンクリートブロックと吸リン剤を用いた池水浄化法 における浄化メカニズムの一考察, 人間と環境, 24, pp.86-92.

[11] 大村恵・瀬戸昌之 (2001)：池水の透視度とクロロフ イルa濃度および全リン・全窒素濃度の関係, 人間と 環境, 27, pp.64-69.

[12] 末次康隆・瀬戸昌之 (1998): ポーラスコンクリートブロッ クと吸リン剂を用いた親水池づくり, 多自然研究, 30, pp.3-10.

[13] 田㴊俊雄 (1985): 降雨中の窒素とリン, 水質污濁研究, 8, pp.486-490.

[14] 渡辺泰徳 (1994): 公園の池, その水の色と質, 水と緑 の読本-特集/公園の水と水辺の管理 (II ), 30, pp. 883-888.

(この論文に対する公開の質疑または討議は2004年12 